\title{
Induction of Microglial Activation by Mediators Released from Mast Cells
}

\author{
Xiang Zhanga,b Yiming Wang ${ }^{a}$ Hongquan Dong ${ }^{a, b} \quad Y^{a}$ Xing $X^{a}$ Shu Zhang \\ ${ }^{a}$ Clinical Research Center, the First Affiliated Hospital of Nanjing Medical University, Nanjing, \\ ${ }^{\text {bDepartment }}$ of Anesthesiology, the First Affiliated Hospital of Nanjing Medical University, Nanjing, P. R. \\ China
}

\section{Key Words}

$\mathrm{HMC}-1 \cdot$ Microglial activation $\bullet \mathrm{CRH} \cdot$ Pro-inflammatory factors $\bullet$ MAPK

\begin{abstract}
Background/Aims: Microglia are the resident immune cells in the brain and play a pivotal role in immune surveillance in the central nervous system (CNS). Brain mast cells are activated in CNS disorders and induce the release of several mediators. Thus, brain mast cells, rather than microglia, are the "first responders" due to injury. However, the functional aspects of mast cellmicroglia interactions remain uninvestigated. Methods: Conditioned medium from activated HMC-1 cells induces microglial activation similar to co-culture of microglia with $\mathrm{HMC}-1$ cells. Primary cultured microglia were examined by flow cytometry analysis and confocal microscopy. TNF- alpha and IL- 6 were measured with commercial ELISA kits. Cell signalling was analysed by Western blotting. Results: In the present study, we found that the conditioned medium from activated HMC-1 cells stimulated microglial activation and the subsequent production of the pro-inflammatory factors TNF- $\alpha$ and IL-6. Co-culture of microglia and HMC-1 cells with corticotropin-releasing hormone $(\mathrm{CRH})$ for 24,48 and 72 hours increased TNF- $\alpha$ and IL-6 production. Antagonists of histamine receptor $1\left(H_{1} R\right), H_{4} R$, proteinase-activated receptor 2 (PAR2) or Toll-like receptor 4 (TLR4) reduced HMC-1-induced pro-inflammatory factor production and MAPK and PI3K/AKT pathway activation. Conclusions: These results imply that activated mast cells trigger microglial activation. Interactions between mast cells and microglia could constitute a new and unique therapeutic target for CNS inflammation-related diseases.

\section{Introduction}

Inflammation is fundamentally a protective cellular response aimed at the removal of injurious stimuli and the initiation of the repair process but can be a driver of disease when it fails to subside [1]. Several studies have demonstrated that neuroinflammation plays an 
important role in the development of neurodegenerative diseases [2-4]. Recent progress suggested that the interaction between glia, immune cells, and neurons contributed to the exacerbation of acute symptoms of chronic neurodegenerative disease and accelerated disease progression. However, the microglia-immune cell connection has not been fully explored.

Microglia are the resident immune cells in the central nervous system (CNS) and secrete proinflammatory molecules that contribute to the pathogenesis of a broad range of CNS disorders. These disorders include not only infectious CNS diseases but also acute CNS injuries such as traumatic brain injury [5], spinal cord injury [6], stroke, and brain ischaemia [7]. Increasing evidence has demonstrated that the microglia-mediated neuroinflammatory process is critically involved in the initiation and development of neurodegenerative disorders such as Parkinson's disease (PD) [8], Alzheimer's disease (AD) [9] and multiple sclerosis [10]. When subjected to abnormal stimulation, such as neurotoxins, neuronal debris, or injury, microglia gradually become activated and produce a host of inflammatory factors. Thus, inhibition of microglial activation and the subsequent inflammatory process may identify novel therapeutic strategies to eliminate the deleterious effects of microglia.

Although microglial activation is widely recognized to participate in neuropathology, we must not ignore the finding that microglia also respond to proinflammatory signals released from other cells of immune origin, such as mast cells (MCs). MCs, which play a notorious role in allergic inflammation, are also found in the CNS where they are concentrated in the brain parenchyma along the blood vessels and leptomeninges $[11,12]$. MCs produce a vast array of mediators, including proteases and vasoactive amines such as GnRH [13] and histamine [14]. MCs were reported to induce microglial activation and inflammatory mediator release in our previous studies $[15,16]$, suggesting the pivotal role of MCs in the induction of CNS inflammation. These neuromodulators released by MCs result in a variety of inflammatory diseases affected by stress [17]. Furthermore, meningeal MCs can recruit early T cells and neutrophils to the CNS, which in turn disrupt the blood-brain barrier [18]. The potential interactions between MCs and microglia, which may be involved in the pathobiology of neuroinflammation, have been reported to be the therapeutic target of neurodegeneration [19]. Yuan reported that mast cell activation induced microglia to release neurotrophin [20]. We previously reported that tryptase and histamine, which are mediators released from MCs, induced microglial activation and inflammatory mediator release $[15,16]$. However, the effect of MCs on microglial activation is unclear. In this study, we investigated whether activated MCs directly evoked microglial activation in vitro.

\section{Materials and Methods}

\section{Reagents}

Dulbecco's modified Eagle's medium (DMEM) and foetal calf serum (FCS) were purchased from GibcoBRL (Grand Island, NY, USA). The specific mouse anti-rat ED8 (anti-CD11b/CD18) monoclonal antibody (a marker for complement receptor 3 of activated microglia) was purchased from AbD Serotec (Raleigh, NC, USA). Fluoroshield mounting medium with 4, 6-diamidino-2-phenylindole (DAPI) was purchased from Abcam (HK, China). The Rat IL-6 Immunoassay Kit and Rat TNF- $\alpha$ Immunoassay Kit were obtained from R\&D Systems, Inc. (Minneapolis, MN, USA). The specific rabbit monoclonal antibodies against p38, phospho-p38, JNK, phospho- JNK, ERK, phospho-ERK, AKT, and phospho-AKT and the goat anti-rabbit secondary antibody were obtained from Cell Signalling (Beverly, MA, USA). The PE-conjugated goat antimouse and FITC-conjugated goat anti-rabbit IgG antibodies were purchased from BD (BD Biosciences, USA). The Toll-like receptor 4 (TLR4) neutralization antibody was purchased from Santa Cruz Biotechnology (Santa Cruz, CA, USA, catalogue number sc-10741). The histamine receptor $1\left(\mathrm{H}_{1} \mathrm{R}\right)$ antagonist cetirizine dihydrochloride (cetirizine), $\mathrm{H}_{2} \mathrm{R}$ antagonist ranitidine hydrochloride (ranitidine), $\mathrm{H}_{3} \mathrm{R}$ antagonist carcinine ditrifluoroacetate (carcinine), $\mathrm{H}_{4} \mathrm{R}$ antagonist $\mathrm{A} 943931$ dihydrochloride (A943931), and NK-1 antagonist L-733060 were purchased from Tocris Bioscience (Bristol, UK). The proteinase-activated receptor 2 (PAR2) inhibitor FSLLRY-NH2 was synthesized by CL Bio-Scientific Inc. (Xi An, China).

\section{KARGER}




\section{Cellular Physiology Cell Physiol Biochem 2016;38:1520-1531 \begin{tabular}{cl|l} 
DOI: 10.1159/000443093 & $\begin{array}{l}\text { O 2016 The Author(s). Published by S. Karger AG, Basel } \\
\text { www.karger.com/cpb }\end{array}$
\end{tabular} \\ Zhang et al.: Mast Cells Induce Microglial Activation}

\section{Microglia-enriched cultures}

Rat primary microglial cells were prepared according to the previously described protocol with slight modifications [21]. Briefly, whole brain tissues from postnatal (P1-P2) Sprague-Dawley rats were triturated. Then, the cells were plated onto poly-D-lysine precoated cell culture flasks in DMEM containing $10 \%$ foetal calf serum, $100 \mathrm{U} / \mathrm{ml}$ penicillin, and $100 \mathrm{mg} / \mathrm{ml}$ streptomycin. The cultures were maintained at $37^{\circ} \mathrm{C}$ in a humidified atmosphere with $5 \% \mathrm{CO}_{2} / 95 \%$ air. After obtaining a confluent monolayer of glial cells (10-14 days), the microglia were separated from the astrocytes by shaking for $5 \mathrm{~h}$ at $100 \mathrm{rpm}$ and replated in 24-well culture plates at a density of $10^{5}$ cells $/ \mathrm{cm}^{2}$. The enriched microglia were $>98 \%$ pure as determined by OX-42-IR.

\section{HMC-1 Cell Culture}

The human MC line HMC-1 was kindly provided by Dr. J. H. Butterfield (Mayo Clinic, Rochester, MN, USA). HMC-1 cells were cultured in DMEM culture medium supplemented with $10 \%$ foetal bovine serum, glutamine $(2 \mu \mathrm{M})$ and penicillin-streptomycin (1:1000).

Co-culture of microglia and HMC-1 cells

Primary brain microglia $\left(1 \times 10^{6}\right.$ cells $)$ was grown in $25 \mathrm{~cm}^{2}$ flasks until confluent. Then, HMC- 1 cells $\left(1 \times 10^{6}\right.$ cells $)$ were added to the microglia flask because the MCs were floating cells. The cells were cocultured for 12, 24, 48 and 72 hours.

\section{Microglial challenge}

Microglial cells were treated with conditioned medium from HMC-1 cells with or without corticotropinreleasing hormone (CRH) treatment for 12, 24, 48 and 72 hours and then incubated for an additional 24 hours.

\section{Flow cytometry analysis}

To determine the effect of HMC-1 cells on microglial activation, microglia were pelleted by centrifugation at $450 \mathrm{x}$ g for $10 \mathrm{~min}$ and then fixed in $4 \%$ paraformaldehyde for $30 \mathrm{~min}$. After washing, the cells were incubated with a PE-conjugated mouse anti-rat ED8 monoclonal antibody or isotype control $(1: 200)$ at $37^{\circ} \mathrm{C}$ for $1 \mathrm{~h}$. Then, the cells were resuspended in PBS and analysed with a FACS Calibur flow cytometer with the CellQuest software (BD Biosciences, USA).

\section{Immunofluorescence}

To determine the effect of HMC-1 cells on microglial activation, microglia was fixed with $4 \%$ paraformaldehyde for $30 \mathrm{~min}$. Nonspecific binding was blocked by incubating the cells in a 5\% BSA and $0.1 \%$ Triton X-100 solution for $1 \mathrm{~h}$ at room temperature. The microglia were incubated with the monoclonal antibody ED8 (1:300) that recognizes complement receptor 3 (CD11b/CD18) overnight at $4^{\circ} \mathrm{C}$. After three washes with PBS, the microglia were incubated with a PE-conjugated secondary antibody (1:200) and the nuclei were stained with DAPI. After three washes in PBS, the cells were smeared onto glass slides and the coverslips were sealed with nail polish. Fluorescent images were acquired using a confocal microscope (Zeiss).

TNF- $\alpha$ and IL-6 assays

The concentrations of TNF- $\alpha$ and IL- 6 in the culture media were measured with commercial ELISA kits from R\&D Systems.

\section{Western Blotting}

Microglia were collected and homogenized in $200 \mu \mathrm{l}$ of lysing buffer. After incubation for $20 \mathrm{~min}$ on ice, the cell lysate was centrifuged and the protein concentration in the extracts was determined by the Bradford assay. Proteins $(50 \mu \mathrm{g})$ in the cell extracts were denatured with sodium dodecyl sulfate (SDS) sample buffer and separated by $10 \%$ SDS-polyacrylamide gel electrophoresis. The proteins were transferred to PVDF membranes (Millipore) using a Bio-Rad miniprotein-III wet transfer unit. The membranes were incubated with 5\% BSA dissolved in Tris-buffered saline with Tween 20 (TBST) (pH 7.5, $10 \mathrm{mM}$ Tris-HCl, $150 \mathrm{mM}$ $\mathrm{NaCl}$, and $0.1 \%$ Tween 20 ) at room temperature for $1 \mathrm{~h}$, followed by incubation of the membranes with 
different antibodies overnight at $4{ }^{\circ} \mathrm{C}$. The following primary antibodies were used: rabbit monoclonal antic-Jun N-terminal kinase (JNK), -phospho-JNK, -p38, -phospho-p38, -ERK, phospho-ERK, -AKT, and -phosphoAKT (1:1000). After adding the goat anti-rabbit secondary antibody (1:1000) for $1 \mathrm{~h}$, the protein bands on the membranes were detected with an enhanced chemiluminescence kit.

\section{Statistical Analysis}

All values are the means \pm SEM. The significance of the differences between the controls and samples treated with various drugs was determined by one-way ANOVA followed by the post-hoc least significant difference test. Differences were considered significant at $\mathrm{P}<0.05$.

\section{Results}

\section{CRH induced HMC-1 activation and mediator release}

The human leukaemic MC (HMC-1) cell line expresses functional CRH receptors and can be activated by CRH $[22,23]$. Therefore, we investigated whether CRH induced proinflammatory factor production from HMC-1 cells. As shown in Fig. 1A, stimulation of HMC-1 cells with CRH caused concentration-dependent (1- $\left.10^{4} \mathrm{nmol}\right)$ and time-dependent ( $>24 \mathrm{~h}$ ) HMC-1 activation indicated by the increase in the Fc-positive cell number. However, $\mathrm{CRH}$ treatment (1- $10^{4} \mathrm{nmol}$ ) for $12 \mathrm{~h}$ had no effect on $\mathrm{HMC}-1$ activation. We also found that incubation with CRH (100 nmol) for more than 48 hours resulted in the production of TNF- $\alpha$ and IL- 6 by the HMC- 1 cells (Fig. 1B). These results indicate that long-term CRH treatment $(>48 \mathrm{~h}$ ) can induce HMC-1 activation and pro-inflammatory factor production.

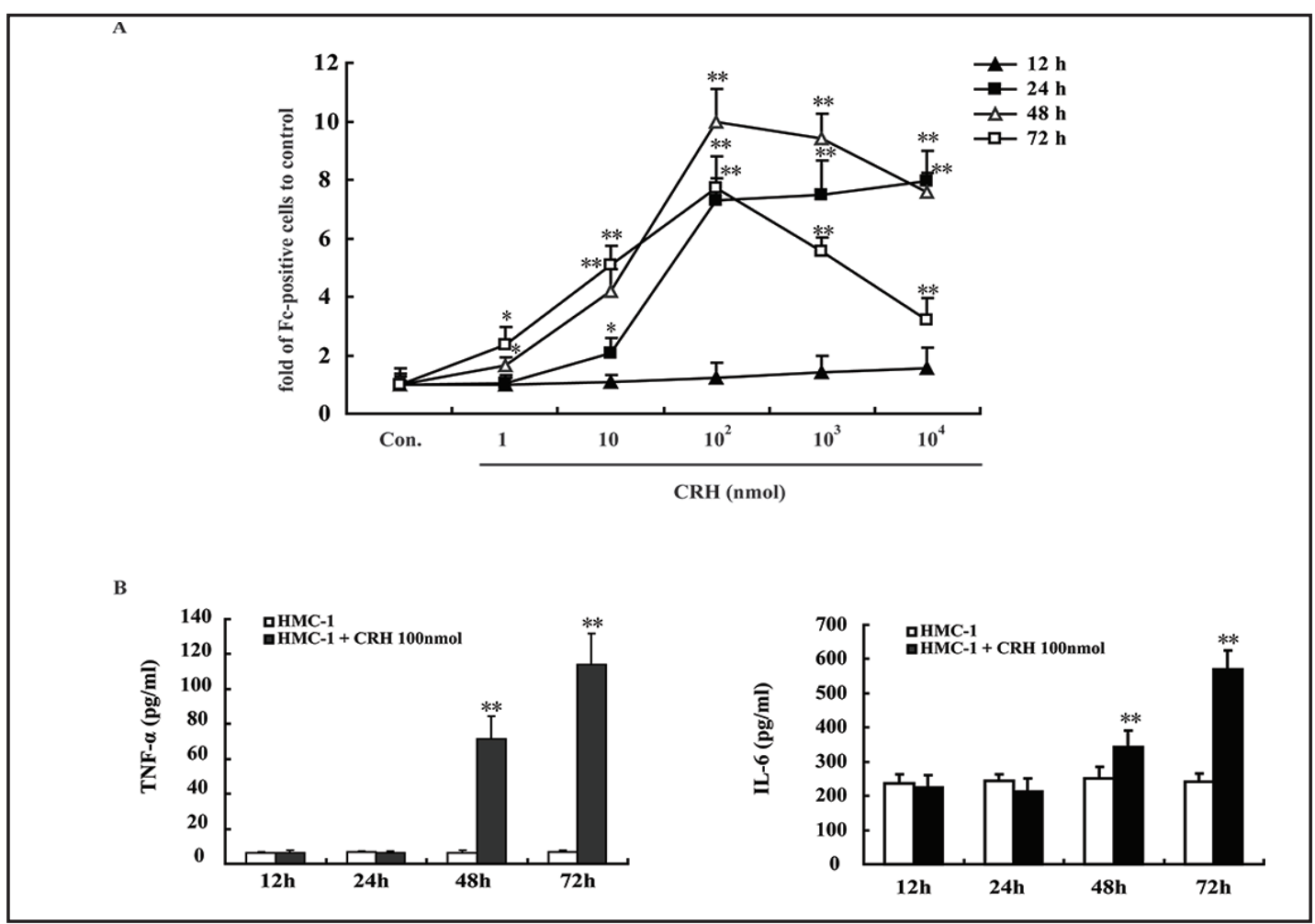

Fig. 1. $\mathrm{CRH}$ induced HMC-1 degranulation. (A) HMC-1 cells were treated with CRH (1-104 nmol) for 24,48 and $72 \mathrm{~h}$, resulting in increased numbers of Fc-positive cells. (B) CRH (100 nmol) induced the release of TNF- $\alpha$ and IL- 6 from HMC- 1 cells following more than $48 \mathrm{~h}$ of incubation. ${ }^{*} P<0.05,{ }^{* *} P<0.01 v s$. the control HMC-1 group. The data are presented as the mean \pm SEM of four independent experiments. 

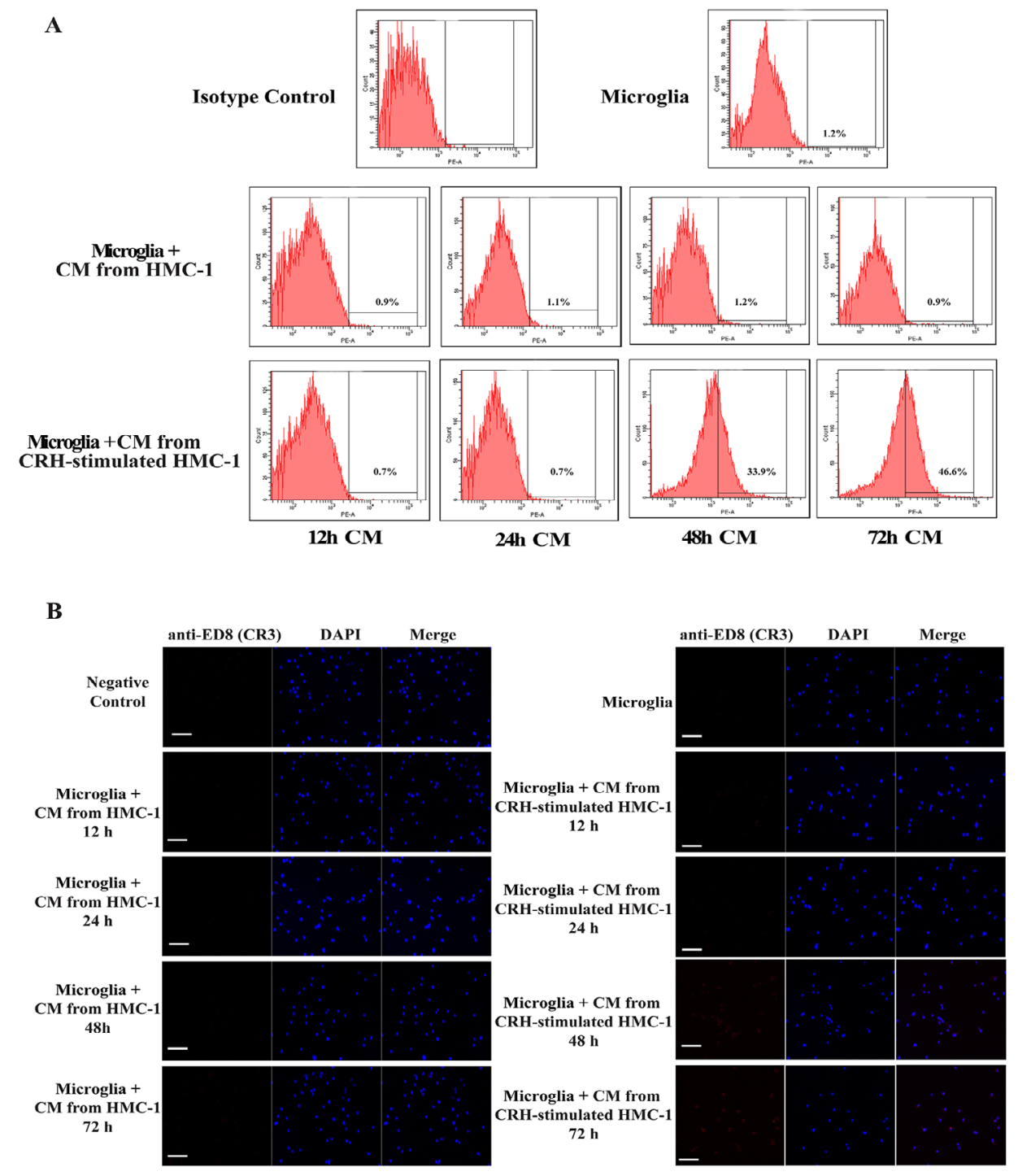

Fig. 2. Activated HMC-1 cells increased microglial activation and TNF- $\alpha$ and IL- 6 production from microglia. Primary microglia were treated with CM from HMC-1 cells with or without CRH stimulation for 24 hours for different incubation times $(12,24,48$ and $72 \mathrm{~h})$. (A) For the flow cytometry analysis, the cells were incubated with a PE-conjugated ED8 antibody at $37^{\circ} \mathrm{C}$ for $1 \mathrm{~h}$. (B) Cells were stained with an ED8 antibody, and upregulated ED8-immunopositive expression (red) on activated microglia was observed using confocal microscopy. The blue staining represented DAPI. Scale bar: $50 \mu \mathrm{m}$.

\section{Activated HMC-1 cells induced microglial activation}

Activated microglia were detected with the monoclonal antibody ED8, which recognizes complement receptor 3 (CR3). Microglia were incubated for 12 hours with CM from HMC-1 cells with or without CRH-stimulation $(12,24,48$ and 72 hours). The flow cytometry analysis showed that approximately $33.9 \%$ and $46.6 \%$ of the microglia were activated by incubation in the CM from HMC-1 cells stimulated with CRH for 48 and 72 hours, respectively. However, the CM from HMC- 1 cells stimulated with CRH for 12 and 24 hours had no effect on microglial activation (Fig. 2A). A $24 \mathrm{~h}$ incubation with the CM from HMC-1 cells stimulated with CRH for 48 and 72 hours resulted in a remarkable upregulation of ED8 expression (in red, Fig. 2B).

\section{KARGER}




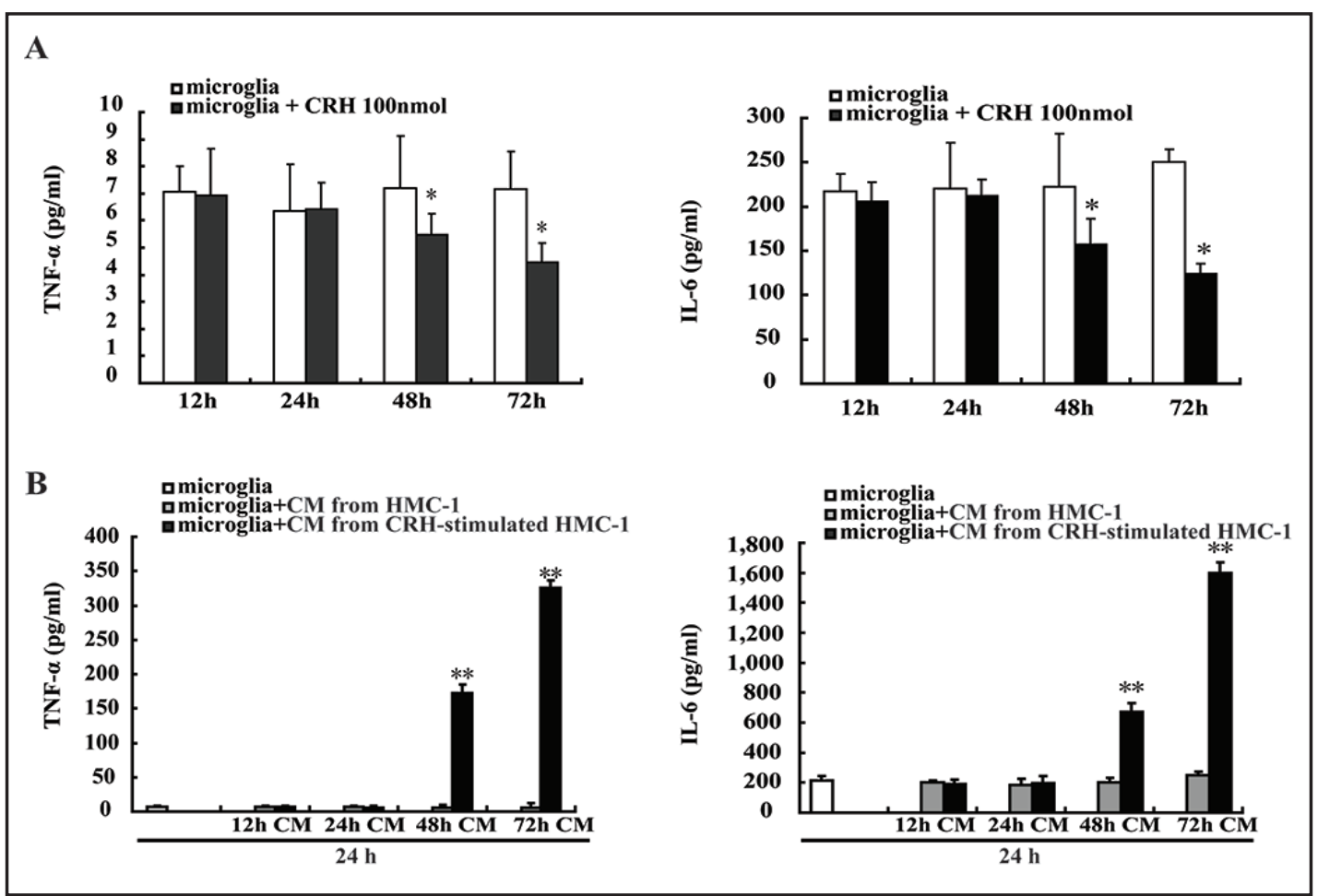

Fig. 3. (A) Incubation of microglia with CRH (100 nmol) for more than $48 \mathrm{~h}$ inhibited TNF- $\alpha$ and IL- 6 production. (B) Incubation of microglia with CM from HMC-1 cells had no effect on TNF- $\alpha$ and IL-6 production, but the CM from CRH-stimulated HMC- 1 cells (48 and 72 hours) induced the release of TNF- $\alpha$ and IL- 6 from microglia following $24 \mathrm{~h}$ of incubation. ${ }^{*} P<0.05,{ }^{* *} P<0.01$ vs. the control microglia group. The data are presented as the mean \pm SEM of four independent experiments.

However, the CM from HMC-1 cells without CRH stimulation had no effect on ED8 expression (Fig. 2B). These results suggested that mediators released from activated HMC-1 cells could activate microglia.

\section{Activated HMC-1 cells induced TNF- $\alpha$ and IL-6 production by microglia}

Because microglia-mediated neuroinflammation primarily occurs through the excessive production of pro-inflammatory and cytotoxic factors from activated microglia and their downstream signalling cascades, we measured the levels of pro-inflammatory factors. As shown in Fig. 3A, incubation with CRH (100 nmol) for 12, 24, 48 and 72 hours did not increase the production of TNF- $\alpha$ and IL-6; indeed, incubation for 48 and $72 \mathrm{~h}$ decreased the production of TNF- $\alpha$ and IL- 6 . Incubation of microglia with the CM from HMC-1 cells without CRH had no effect on TNF- $\alpha$ and IL- 6 production, whereas the CM from CRH-stimulated HMC-1 cells (48 and 72 hours) induced the release of TNF- $\alpha$ (172 and $326 \mathrm{pg} / \mathrm{ml}$ ) and IL-6 ( 669 and $1599 \mathrm{pg} / \mathrm{ml}$ ) from the microglia following $24 \mathrm{~h}$ of incubation (Fig. 3B).

To confirm that activated HMC-1 cells induced the release of pro-inflammatory factors from microglia, we co-cultured microglia with HMC-1 cells. As shown in Fig. 4, microglia and HMC-1 cells were co-cultured with or without CRH (100 nmol) for 12, 24, 48 and 72 hours. The co-culture of microglia and HMC-1 cells with CRH for 24, 48 and 72 hours resulted in increased TNF- $\alpha$ and IL- 6 production compared with the culture of microglia alone.

\section{The effect of receptor antagonists on HMC-1-induced microglial activation}

MCs contain an array of chemical mediators that can be released to the micromilieu upon activation. To elucidate which mediators were involved in the promotion of microglial activation, we selectively blocked the histamine receptors PAR2, NK-1 and TLR4 in MCs [15, 


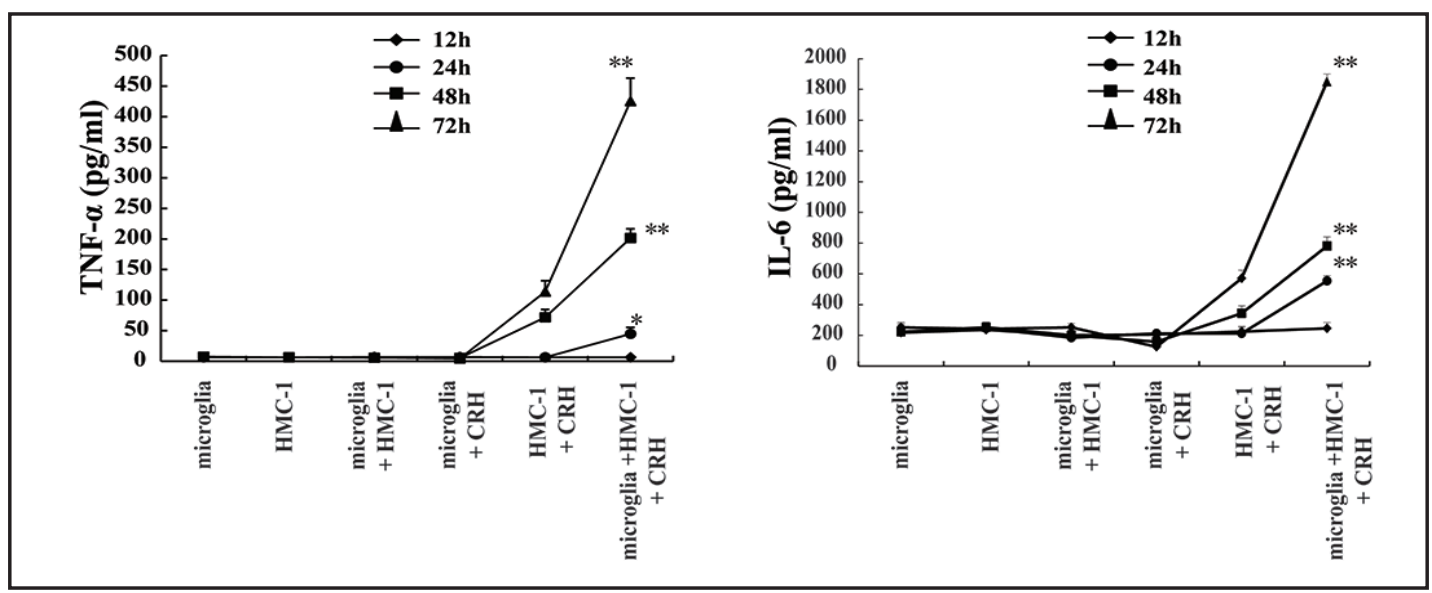

Fig. 4. Co-culture of microglia with HMC-1 cells. The TNF- $\alpha$ and IL-6 levels in the CRH co-culture group were higher than the other groups after $24 \mathrm{~h}$ of incubation. ${ }^{*} P<0.05,{ }^{* *} P<0.01 \mathrm{vs}$. the control microglia group. The data are presented as the mean \pm SEM of four independent experiments.

Fig. 5. Antagonists of $\mathrm{H}_{1} \mathrm{R}, \mathrm{H}_{4} \mathrm{R}, \mathrm{PAR} 2$ or TLR4 partially inhibited HMC-1-induced TNF- $\alpha$ and IL-6 production in microglia. CM from $\mathrm{CRH}$-stimulated HMC-1 cells ( $48 \mathrm{~h}$ ) was incubated with microglia at $37^{\circ} \mathrm{C}$ for 24 h. ${ }^{* *} P<0.01,{ }^{*} P<0.05$ vs. the control microglia group. ${ }^{\#} P<0.05$ vs. CM from CRH-stimulated HMC-1 treatment group. The data are presented as the mean \pm SEM of four independent experiments.

16]. As shown in Fig. 5 , the $H_{1} R$ antagonist cetirizine $(10 \mu \mathrm{M}), \mathrm{H}_{4} \mathrm{R}$ antagonist A943931 $(10 \mu \mathrm{M})$, PAR2 inhibitor FSLLRY-NH2 (400 $\mu \mathrm{M})$ and TLR4 neutralizing antibody $(10 \mu \mathrm{g} /$ $\mathrm{ml}$ ) partially abolished the ability of CM from CRH-stimulated HMC- 1 cells to induce TNF- $\alpha$ and IL- 6 release from microglia. Conversely, the $\mathrm{H}_{2} \mathrm{R}$ antagonist ranitidine $(10 \mu \mathrm{M}), \mathrm{H}_{3} \mathrm{R}$ antagonist carcinine ditrifluoroacetate $(10$ $\mu \mathrm{M})$ and NK-1 antagonist L-733060 (100 $\mu \mathrm{m}$ ) had little effect on the ability of activated HMC-1 cells to induce TNF- $\alpha$ and IL-6 production from microglia. These results indicated that activated HMC-1 cells induced

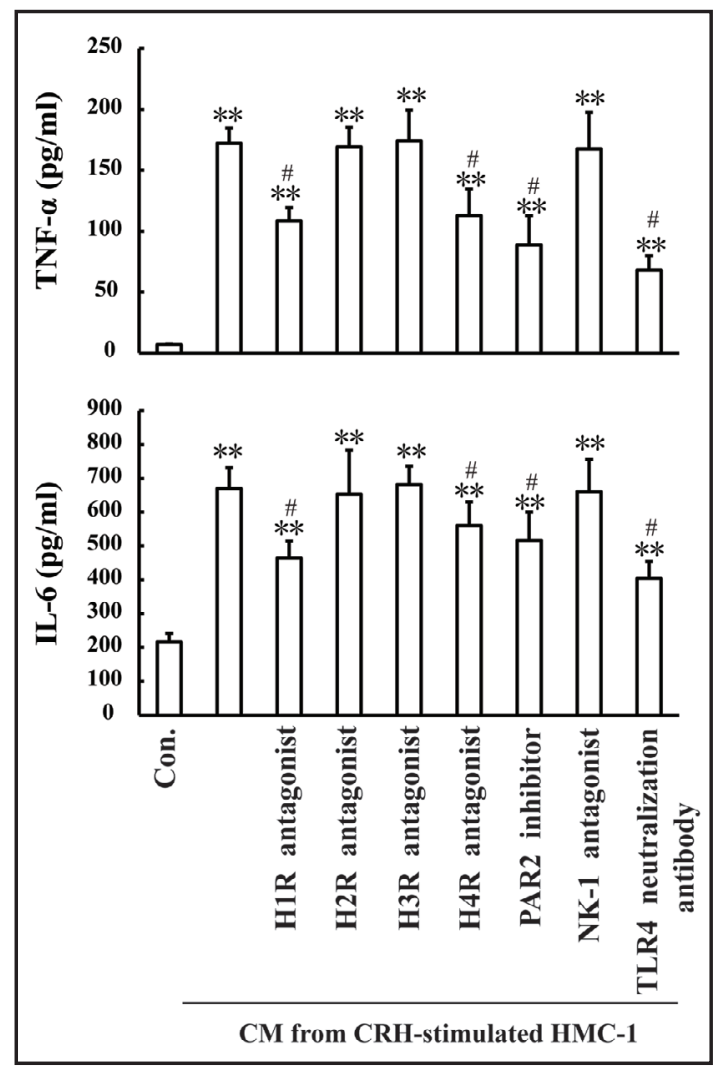
TNF- $\alpha$ and IL- 6 production from microglia partially through the activation of $\mathrm{H}_{1} \mathrm{R}, \mathrm{H}_{4} \mathrm{R}, \mathrm{PAR} 2$ and TLR4.

The MAPK and AKT pathways mediated MC-induced microglial activation

We found that the MAPK and AKT signalling pathways were involved in MC- induced microglial activation in vivo [24]. To confirm this finding, we investigated these signalling pathways in vitro. Treatment with CM from CRH-stimulated HMC-1 cells (48 h) led to rapid and transient phosphorylation of ERK, p38, JNK and AKT that was indicative of ERK, p38, JNK and AKT activation, with the peak levels of phospho-ERK occurring at $60 \mathrm{~min}$, phospho-p38 occurring at $15 \mathrm{~min}$, phospho-JNK occurring at $120 \mathrm{~min}$ and phospho-AKT occurring at 120 


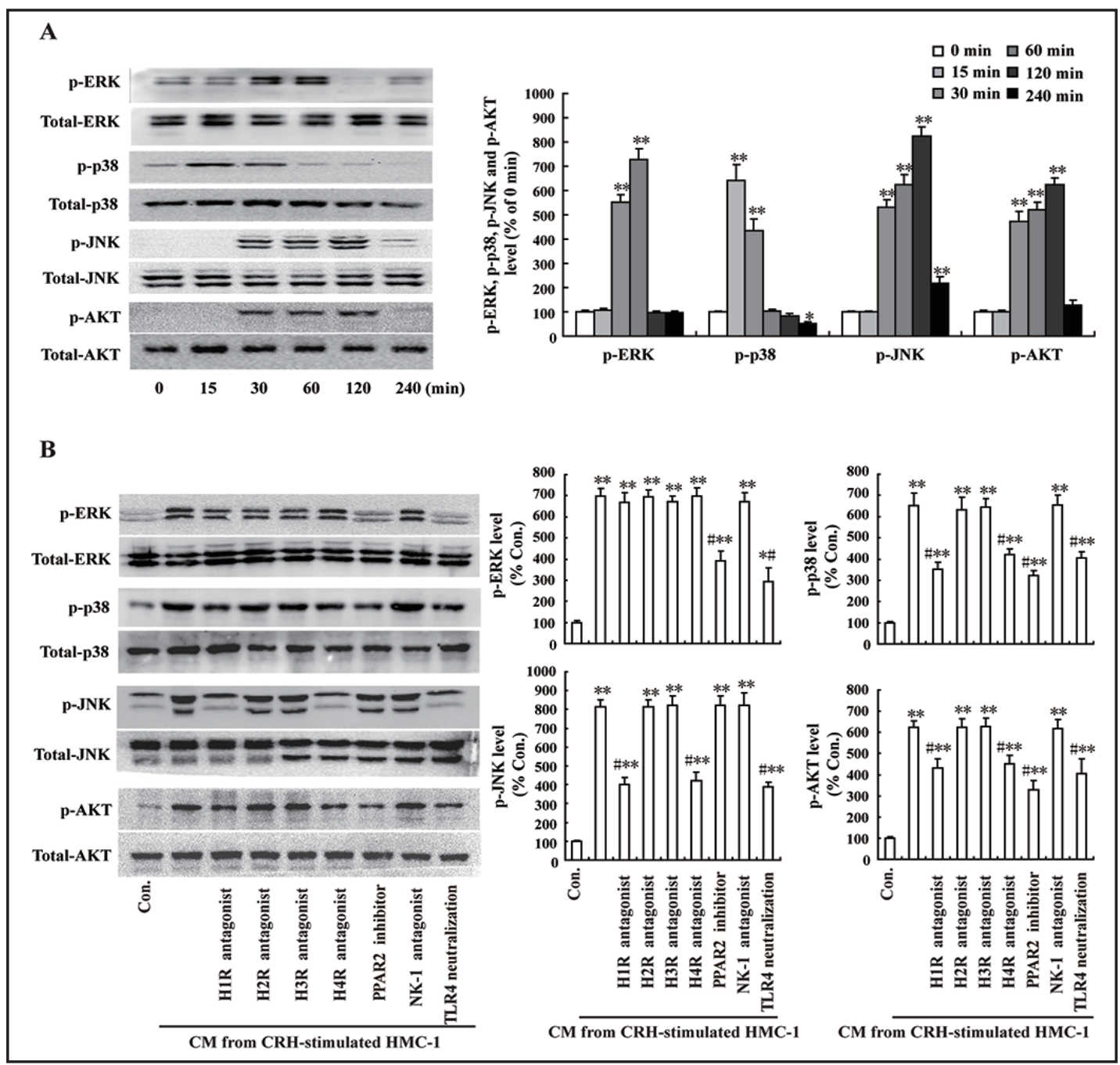

Fig. 6. Effects of the $\mathrm{H}_{1} \mathrm{R}, \mathrm{H}_{4} \mathrm{R}, \mathrm{PAR} 2$ and TLR4 antagonists on HCM-1-induced MAPK and PI3K/AKT activation. (A) CM from CRH-stimulated HMC-1 cells (48 h) activated ERK, p38, JNK and AKT as assessed by the increased phosphorylation of the tyrosine residues of these kinases. (B) The $\mathrm{H}_{1} \mathrm{R}$ and $\mathrm{H}_{4} \mathrm{R}$ antagonists suppressed the ability of CM from CRH-stimulated HMC-1 cells (48 h) to induce p38, JNK and AKT activation in microglia. The PAR2 antagonist suppressed the ability of the CM from CRH-stimulated HMC-1 cells ( $48 \mathrm{~h}$ ) to induce ERK, JNK and AKT activation in microglia. The TLR4 antagonist suppressed the ability of the CM from CRH-stimulated HMC-1 cells ( $48 \mathrm{~h}$ ) to induce ERK, p38, JNK and AKT activation in microglia. Microglia were pretreated with the antagonists for $30 \mathrm{~min}$ and then exposed to CM from CRH-stimulated HMC-1 cells (48 h) for $60 \mathrm{~min}$ (p-ERK), $15 \mathrm{~min}$ (p-p38), $120 \mathrm{~min}$ (p-JNK) or $120 \mathrm{~min}$ (p-AKT). ${ }^{*} P<0.05,{ }^{* *} P<0.01 v s$. the control microglia group. ${ }^{\#} P<0.05$ vs. CM from the CRH-stimulated HMC-1 treatment group. Data are presented as the mean \pm SEM of three independent experiments.

min (Fig. 6A). These data indicate that the MAPK and AKT signalling pathways are involved in HMC-1-induced microglial activation. As shown in Fig. 6B, the TLR4 neutralizing antibody $(10 \mu \mathrm{g} / \mathrm{ml})$ suppressed the ability of HMC- 1 cells to induce the activation of all three mitogenactivated protein kinases (MPAK) and AKT phosphorylation in microglia. However, the $H_{1} R$ antagonist cetirizine $(10 \mu \mathrm{M})$ and $\mathrm{H}_{4} \mathrm{R}$ antagonist A943931 $(10 \mu \mathrm{M})$ suppressed JNK, p38 and AKT phosphorylation and the PAR2 inhibitor FSLLRY-NH2 $(400 \mu \mathrm{M})$ suppressed ERK, p38 and AKT phosphorylation in microglia. These results indicate that HMC-1 activates the MAPK and AKT signalling pathways via $\mathrm{H}_{1} \mathrm{R}, \mathrm{H}_{4} \mathrm{R}$, PAR2 and TLR4 in microglia. 


\section{Cellular Physiology Cell Physiol Biochem 2016;38:1520-1531 \\ and Biochemistry Published online: April 07, $2016 \quad \begin{aligned} & \text { DOI: 10.1159/000443093 } 2016 \text { The Author(s). Published by S. Karger AG, Basel } \\ & \text { www.karger.com/cpb }\end{aligned}$ \\ Zhang et al.: Mast Cells Induce Microglial Activation}

\section{Discussion}

Pathological mechanisms that regulate neuroinflammation, which plays an important role in provoking the occurrence and development of neurodegenerative diseases, may prove to be a useful therapeutic target for central nervous system disorders. This finding also raises the question of whether we are missing important therapeutic avenues by studying microglia and MCs in isolation [19]. Our previous study showed that the neuromediators histamine and SP triggered microglial activation, indicating the possibility of communication between MCs and microglia [25]. However, direct evidence concerning whether MCs could affect microglial activation was lacking. In this study, we found that activated MCs induced TNF- $\alpha$ and IL- 6 production from microglia partially via $\mathrm{H}_{1} \mathrm{R}, \mathrm{H}_{4} \mathrm{R}, \mathrm{PAR} 2$, and TLR4-MAPK. These results may provide novel therapeutic targets for the treatment of neuroinflammation.

Emerging evidence now points to the irremissible responsibility of neuroinflammation in pathophysiology onsetand progression, with microglia playing key roles in neurodegenerative diseases such as PD [26, 27], AD [28-31], amyotrophic lateral sclerosis [32], and possibly even depression, schizophrenia, and other psychiatric disorders [33, 34]. Our previous in vitro study suggested that high glucose augmented LPS-induced microglial activation and inflammatory cytokine levels, which offered new insight into the pathophysiological relationship between diabetes mellitus and POCD [35]. Our in vivo study showed that S100A8 resulted in microglial activation following the occurrence and development of surgery-induced neuroinflammation and cognitive dysfunction [36]. Activated microglia can release BDNF, which causes prolonged microglial activation [37]. Therefore, the inhibition of microglial activation and subsequent neuroinflammation may offer prospective clinical therapeutic benefits for neuroinflammation-related neurodegenerative disorders. However, the factors responsible for the overactivation of microglia are largely undefined.

A previous study suggested that activated MCs but not microglia were the "first responders" in brain injury [38]. Although other resident cells in the CNS produce TNF- $\alpha$ (most notably microglia [39, 40] and endothelial cells [41]), the presence and release of TNF- $\alpha$ from MCs precedes its detection in other cells. Recent in vivo studies indicated that MCs actively participated in the pathogenesis of inflammation through the release of proinflammatory mediators. If early MC activation is necessary for the initiation of the inflammatory cascade and ultimately tissue damage, the inhibition of this response should be neuroprotective. In the present study, we found that only CRH-stimulated HMC-1 cells activated microglia and induced TNF- $\alpha$ and IL- 6 release. HMC- 1 is an immature MC line that can be activated by CRH $[22,23]$. We found that incubation with CRH $(100 \mathrm{nmol})$ for more than 48 hours resulted in the activation of HMC-1 cells and the production of TNF- $\alpha$ and IL-6. Conversely, HMC-1 cells cultured in the absence of CRH had no effect on microglial activation. These results confirm that only activated MCs can induce microglial activation and pro-inflammatory factor release.

The factors responsible for the overactivation of microglia are largely undefined. Several molecular mechanisms for potential communications between MCs and microglia have been determined in vitro [19]. For instance, ATP can stimulate the activation of microglia through purinergic P2 receptors and the subsequent release of IL-33. IL-33 binds to MC receptors and triggers the production of monocyte chemo-attractant protein 1, IL-6 and IL-13, which in turn may regulate microglial activity. Similarly, tryptase released from MCs activates the microglial PAR-2 receptors, thereby initiating the production of inflammatory mediators such as TNF- $\alpha$, IL- 6 , and ROS that consequently upregulate the expression of PAR2 receptors on MCs $[15,42]$. Our previous studies showed the presence of tryptase and histamine receptors on the surface of microglia. Tryptase can induce microglial activation and proinflammatory mediator release via the protease-activated receptor 2 (PAR2)-MAPKNF-kappa B signalling pathway, whereas histamine induces TNF- $\alpha$ and IL-6 release from activated microglia via the $\mathrm{H}_{1} \mathrm{R}, \mathrm{H}_{4} \mathrm{R}-\mathrm{MAPK}$ and PI3K/AKT-NF-kappa B signalling pathways[15, 16]. Here, we demonstrate that mediators released from activated MCs can induce microglial activation through $\mathrm{H}_{1} \mathrm{R}, \mathrm{H}_{4} \mathrm{R}, \mathrm{PAR} 2$ and TLR4 in the microglia. The antagonists of $\mathrm{H}_{1} \mathrm{R}, \mathrm{H}_{4} \mathrm{R}$, 


\section{Cellular Physiology Cell Physiol Biochem 2016;38:1520-1531

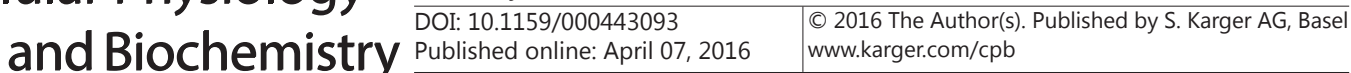 \\ Zhang et al.: Mast Cells Induce Microglial Activation}

PAR2 and TLR4 inhibited activated HMC-1-induced microglial activation in our in vitro study. The MAPK and AKT signalling pathways were involved. All of the above results imply that activated MCs trigger microglial activation and subsequent neuroinflammation. Therefore, the communication of MCs with microglia could constitute a new and unique therapeutic target for CNS immune inflammation-related diseases.

In conclusion, to the best of our knowledge this is the first study to demonstrate the direct effect of MCs on microglia and the involved signalling pathways. Activated MCs can trigger microglial activation via $\mathrm{H}_{1} \mathrm{R}, \mathrm{H}_{4} \mathrm{R}, \mathrm{PAR} 2$ and TLR4, which suggests that interactions between MCs and microglia may constitute a new and unique therapeutic target for CNS immune inflammation-related diseases.

\section{Acknowledgements}

This project was sponsored by the National Natural Science Foundation of China (No. 81102422 and 81373398) and a Project Funded by the Priority Academic Program Development of Jiangsu Higher Education Institutions (PAPD).

\section{Disclosure Statement}

The authors declare that there is no conflict of interest regarding the publication of this paper.

\section{References}

$1 \quad$ Nathan C, Ding A: Nonresolving inflammation. Cell 2010;140:871-882.

2 Amor S, Woodroofe MN: Innate and adaptive immune responses in neurodegeneration and repair. Immunology 2014;141:287-291.

3 Waisman A, Liblau RS, Becher B: Innate and adaptive immune responses in the CNS. Lancet Neurol 2015;14:945-955.

4 McGeer PL, McGeer EG: The amyloid cascade-inflammatory hypothesis of Alzheimer disease: Implications for therapy. Acta Neuropathol 2013;126:479-497.

5 Csuka E, Hans VH, Ammann E, Trentz O, Kossmann T, Morganti-Kossmann MC: Cell activation and inflammatory response following traumatic axonal injury in the rat. Neuroreport 2000;11:2587-2590.

6 Popovich PG: Immunological regulation of neuronal degeneration and regeneration in the injured spinal cord. Prog Brain Res 2000;128:43-58.

7 Stoll G, Jander S, Schroeter M: Inflammation and glial responses in ischemic brain lesions. Prog Neurobiol 1998;56:149-171.

8 Gao HM, Liu B, Zhang W, Hong JS: Novel anti-inflammatory therapy for Parkinson's disease. Trends Pharmacol Sci 2003;24:395-401.

9 McGeer PL, McGeer EG: The inflammatory response system of brain: Implications for therapy of Alzheimer and other neurodegenerative diseases. Brain Res Brain Res Rev 1995;21:195-218.

10 Heppner FL, Greter M, Marino D, Falsig J, Raivich G, Hovelmeyer N, Waisman A, Rulicke T, Prinz M, Priller J, Becher B, Aguzzi A: Experimental autoimmune encephalomyelitis repressed by microglial paralysis. Nat Med 2005;11:146-152.

11 Florenzano F, Bentivoglio M: Degranulation, density, and distribution of mast cells in the rat thalamus: A light and electron microscopic study in basal conditions and after intracerebroventricular administration of nerve growth factor. J Comp Neurol 2000;424:651-669.

12 Khalil M, Ronda J, Weintraub M, Jain K, Silver R, Silverman AJ: Brain mast cell relationship to neurovasculature during development. Brain Res 2007;1171:18-29.

13 Khalil MH, Silverman AJ, Silver R: Mast cells in the rat brain synthesize gonadotropin-releasing hormone. J Neurobiol 2003;56:113-124. 


\section{Cellular Physiology Cell Physiol Biochem 2016;38:1520-1531 \begin{tabular}{l|l} 
and Biochemistry & $\begin{array}{l}\text { DOI: 10.1159/000443093 } 216 \\
\text { Published online: April 07,2016 The Author(s). Published by S. Karger AG, Basel }\end{array}$ \\
\hline www.karger.com/cpb
\end{tabular} \\ Zhang et al.: Mast Cells Induce Microglial Activation}

14 Ikarashi Y, Yuzurihara M: Experimental anxiety induced by histaminergics in mast cell-deficient and congenitally normal mice. Pharmacol Biochem Behav 2002;72:437-441.

15 Zhang S, Zeng X, Yang H, Hu G, He S: Mast cell tryptase induces microglia activation via protease-activated receptor 2 signaling. Cell Physiol Biochem 2012;29:931-940.

16 Dong H, Zhang W, Zeng X, Hu G, Zhang H, He S, Zhang S: Histamine induces upregulated expression of histamine receptors and increases release of inflammatory mediators from microglia. Mol Neurobiol 2014;49:1487-1500.

17 Theoharides TC, Cochrane DE: Critical role of mast cells in inflammatory diseases and the effect of acute stress. J Neuroimmunol 2004;146:1-12.

18 Sayed BA, Christy AL, Walker ME, Brown MA: Meningeal mast cells affect early T cell central nervous system infiltration and blood-brain barrier integrity through TNF: A role for neutrophil recruitment? J Immunol 2010;184:6891-6900.

19 Skaper SD, Giusti P, Facci L: Microglia and mast cells: Two tracks on the road to neuroinflammation. FASEB J 2012;26:3103-3117.

20 Yuan H, Zhu X, Zhou S, Chen Q, Zhu X, Ma X, He X, Tian M, Shi X: Role of mast cell activation in inducing microglial cells to release neurotrophin. J Neurosci Res 2010;88:1348-1354.

21 Gao HM, Hong JS, Zhang W, Liu B: Distinct role for microglia in rotenone-induced degeneration of dopaminergic neurons. J Neurosci 2002;22:782-790.

22 Cao J, Papadopoulou N, Kempuraj D, Boucher WS, Sugimoto K, Cetrulo CL, Theoharides TC: Human mast cells express corticotropin-releasing hormone (CRH) receptors and CRH leads to selective secretion of vascular endothelial growth factor. J Immunol 2005;174:7665-7675.

23 Wallon C, Yang PC, Keita AV, Ericson AC, McKay DM, Sherman PM, Perdue MH, Soderholm JD: Corticotropinreleasing hormone $(\mathrm{CRH})$ regulates macromolecular permeability via mast cells in normal human colonic biopsies in vitro. Gut 2008;57:50-58.

24 Dong H, Zhang X, Wang Y, Zhou X, Qian Y, Zhang S: Suppression of Brain Mast Cells Degranulation Inhibits Microglial Activation and Central Nervous System Inflammation. Mol Neurobiol DOI: 10.1007/s12035-0169720-x.

25 Zhu J, Qu C, Lu X, Zhang S: Activation of microglia by histamine and substance P. Cell Physiol Biochem 2014;34:768-780.

26 Fellner L, Jellinger KA, Wenning GK, Stefanova N: Glial dysfunction in the pathogenesis of alphasynucleinopathies: Emerging concepts. Acta Neuropathol 2011;121:675-693.

27 Barcia C, Ros CM, Annese V, Gomez A, Ros-Bernal F, Aguado-Llera D, Martinez-Pagan ME, de Pablos V, Fernandez-Villalba E, Herrero MT: IFN-gamma signaling, with the synergistic contribution of TNF-alpha, mediates cell specific microglial and astroglial activation in experimental models of Parkinson's disease. Cell Death Dis 2012;3:e379.

28 Prat A, Behrendt M, Marcinkiewicz E, Boridy S, Sairam RM, Seidah NG, Maysinger D: A novel mouse model of alzheimer's disease with chronic estrogen deficiency leads to glial cell activation and hypertrophy. J Aging Res 2011;2011:1-12.

29 Sailasuta N, Harris K, Tran T, Ross B: Minimally invasive biomarker confirms glial activation present in Alzheimer's disease: A preliminary study. Neuropsychiatr Dis Treat 2011;7:495-499.

30 Song M, Jin J, Lim JE, Kou J, Pattanayak A, Rehman JA, Kim HD, Tahara K, Lalonde R, Fukuchi K: TLR4 mutation reduces microglial activation, increases Abeta deposits and exacerbates cognitive deficits in a mouse model of Alzheimer's disease. J Neuroinflammation 2011;8:92.

31 Cho SH, Sun B, Zhou Y, Kauppinen TM, Halabisky B, Wes P, Ransohoff RM, Gan L: CX3CR1 protein signaling modulates microglial activation and protects against plaque-independent cognitive deficits in a mouse model of Alzheimer disease. J Biol Chem 2011;286:32713-32722.

32 Appel SH, Zhao W, Beers DR, Henkel JS: The microglial-motoneuron dialogue in ALS. Acta Myol 2011;30:48.

33 Mitterauer BJ: Possible role of glia in cognitive impairment in schizophrenia. CNS Neurosci Ther 2011;17:333-344.

34 Hinwood M, Morandini J, Day TA, Walker FR: Evidence that microglia mediate the neurobiological effects of chronic psychological stress on the medial prefrontal cortex. Cereb Cortex 2012;22:1442-1454.

35 Zhang X, Dong H, Zhang S, Lu S, Sun J, Qian Y: Enhancement of LPS-Induced microglial inflammation response via TLR4 under high glucose conditions. Cell Physiol Biochem 2015;35:1571-1581. 


\section{Cellular Physiology Cell Physiol Biochem 2016;38:1520-1531 \begin{tabular}{ll|l} 
DOI: 10.1159/000443093 & $\begin{array}{l}\text { O 2016 The Author(s). Published by S. Karger AG, Basel } \\
\text { www.karger.com/cpb }\end{array}$
\end{tabular} \\ Zhang et al.: Mast Cells Induce Microglial Activation}

36 Lu SM, Yu CJ, Liu YH, Dong HQ Zhang X, Zhang SS, Hu LQ Zhang F, Qian YN, Gui B: S100A8 contributes to postoperative cognitive dysfunction in mice undergoing tibial fracture surgery by activating the TLR4/ MyD88 pathway. Brain Behav Immun 2015;44:221-234.

37 Zhang X, Zeng L, Yu T, Xu Y, Pu S, Du D, Jiang W: Positive feedback loop of autocrine BDNF from microglia causes prolonged microglia activation. Cell Physiol Biochem 2014;34:715-723.

38 Jin Y, Silverman AJ, Vannucci SJ: Mast cells are early responders after hypoxia-ischemia in immature rat brain. Stroke 2009;40:3107-3112.

39 Gregersen R, Lambertsen K, Finsen B: Microglia and macrophages are the major source of tumor necrosis factor in permanent middle cerebral artery occlusion in mice. J Cereb Blood Flow Metab 2000;20:53-65.

40 Lambertsen KL, Meldgaard M, Ladeby R, Finsen B: A quantitative study of microglial-macrophage synthesis of tumor necrosis factor during acute and late focal cerebral ischemia in mice. J Cereb Blood Flow Metab 2005;25:119-135.

41 Hallenbeck JM: The many faces of tumor necrosis factor in stroke. Nat Med 2002;8:1363-1368.

42 Zhang H, Yang H, He S: TNF increases expression of IL-4 and PARs in mast cells. Cell Physiol Biochem 2010;26:327-336. 